\title{
Mirosław Wojnicki
}

Oil and Gas Institute - National Research Institute

\section{Experimental investigations of oil displacement using the WAG method with carbon dioxide}

\begin{abstract}
The article presents results of experimental studies of oil displacement efficiency by Water Alternating Gas (WAG) injection using carbon dioxide. WAG process was implemented as a tertiary recovery method, after waterflooding. The experiments were conducted on a long-core reservoir model at thermobaric conditions, which are characteristic for Polish carbonate reservoirs. Carbon dioxide injection was performed under miscible conditions (above minimum miscibility pressure). The results have practical importance because they confirm the suitability of conducting WAG process analysis on mentioned reservoir model and they present the WAG method effectiveness in specific reservoir conditions.
\end{abstract}

Key words: enhanced oil recovery, $\mathrm{CO}_{2}-\mathrm{EOR}, \mathrm{WAG}$, recovery factor.

\section{Eksperymentalne badania wypierania ropy metodą WAG z wykorzystaniem dwutlenku węgla}

W artykule przedstawiono wyniki badań eksperymentalnych nad skutecznością wypierania ropy, metodą naprzemiennego zatłaczania wody i gazu (z ang. Water Alternating Gas - WAG), z wykorzystaniem dwutlenku węgla. Proces WAG zastosowano jako metodę trzecią wspomagania wydobycia, po uprzednim procesie nawadniania. Badania przeprowadzono na fizycznym modelu złoża, zbudowanym z długich rdzeni wiertniczych, w warunkach termobarycznych charakterystycznych dla polskich złóż ropy w kolektorach węglanowych. Zatłaczanie dwutlenku węgla odbywało się w warunkach mieszających (powyżej minimalnego ciśnienia zmieszania). Uzyskane wyniki mają charakter praktyczny, gdyż potwierdzają stosowność prowadzenia analiz procesu WAG na wspomnianym modelu złoża oraz przedstawiają skuteczność metody w konkretnych warunkach złożowych.

Słowa kluczowe: wspomaganie wydobycia ropy, $\mathrm{CO}_{2}-\mathrm{EOR}$, WAG, współczynnik odropienia.

\section{Introduction}

The current situation in the domestic oil industry, where on the one hand sustainable growth generates more demand for oil, while on the other hand, the lack of particular achievements in discovering new reservoirs, leads to rational use of the already discovered resources. In this perspective, enhancing mining through the implementation of Enhanced Oil Recovery (EOR) methods, which are suitably adapted to reservoir conditions, is a highly beneficial solution. The average level of the recovery factor for oil reservoirs in Poland is around $20 \%$, while in other parts of the globe (e.g. the North Sea), with the use of secondary and tertiary methods, a recovery factor of $50 \%$ is achieved. This gives a certain view on the scale of the problem $[6,7]$.

Gas injection is the second most widely used EOR method in the world's oil \& gas industry, just after thermal methods.
The major problem associated with gas injection into the oil reservoir, is the unfavorable mobility ratio (associated with the large difference in viscosity) of the displacing and displaced medium. The injected gas tends to migrate to higher permeability zones, which results in gravity tonguing and viscous fingering. These are unfavourable phenomena leading to the destabilization of the displacement front and the premature breakthrough of the gas into the producing wells $[3,4]$. To counteract these negative effects Caudle and Dyes in 1958 [2] proposed simultaneous injection of water with gas into the reservoir. Water allowed the reduction of the mobility of displacement fluids and stabilised the displacement front. Based on the experience of using this method in reservoir conditions it has been found that injection of fluids is less problematic and more efficient when carried out in separate cycles of 
water and gas [1]. Water Alternating Gas (WAG) prevents the occurrence of transient flow in the reservoir, reduces the amount of gas needed, and results in more uniform and efficient displacement of oil compared to injecting only gas or water. Comprehensive information about the WAG process, as well as its practical application in the global oil industry, can be found in another publication of the author [12].

The additional advantage of the WAG method, is the potential for carbon dioxide/flue gases/post-process gases to be used in the injection process and thus to exclude them from the atmospheric circulation. This brings tangible ben- efits to the fight against global warming and still-increasing greenhouse gases emissions limits. Simulation studies conducted at the Oil and Gas Institute - National Research Institute have yielded positive results of the WAG process to support oil extraction $[8,9]$. In Poland no experimental research has been conducted on oil displacement with the mentioned method, nor has it been used in field practice until now, making it unique on a national scale. Detailed laboratory studies coupled with reservoir simulations are crucial for achieving positive implementation of the method on a specific reservoir.

\section{Experimental methodology}

The aim of the experimental laboratory research was to determine the efficiency of oil displacement in the WAG process, using water and acid gas, on a physical model of a reservoir made of long drilling cores. The WAG process was used as a tertiary enhanced recovery method, after a waterflooding process. Experiments were conducted in thermobaric conditions, characteristic for large Polish oil reservoirs in the Main Dolomite $\left(\mathrm{T}=119^{\circ} \mathrm{C}, \mathrm{P}=350 \mathrm{bar}\right)$. The $\mathrm{WAG}$ process was performed under oil-gas miscible conditions. The Minimum Miscibility Pressure (MMP) for the fluids used in the experiments was determined using the advanced PVTsim simulator (with the algorithms proposed by Wang and Orr [11]) and the reservoir fluid model. For the first-contact miscibility, MMP was 202 bar, while for the multiple-contact, miscibility was 157 bar. The vaporizing mechanism was responsible for about $67 \%$ of the miscibility process. Seven series of experiments distinguished by the WAG process parameters (slug size, WAG ratio, and WAG injection scheme) were conducted to determine their influence on the recovery factor $(\mathrm{RF})$. Beside standard WAG injection scheme, two studies used a gradual decrease in the amount of water (tapering). This injection pattern is sometimes distinguished as a separate variant of the method - tapered WAG (TWAG) $[4,10]$.

\section{Research materials}

In the experiments live crude oil was used, which was made by recombination of surface separator oil and gas samples from a reservoir located in the Polish Lowlands. As an irreducible and displacement water, a mixture of brine (from the same reservoir as the oil) and distilled water in a ratio of $1: 1(v / v)$ was used. Due to the experimental nature of the work, one-component acid gas in the form of carbon dioxide was used (as potentially less problematic than its mixtures with $\mathrm{H}_{2} \mathrm{~S}$ ).

The coreflooding process was carried out on a set of four dolomite cores (main dolomite $-\mathrm{Ca} 2$ ) with a diameter of
Table 1. Basic petrophysical properties of cores used in coreflooding

\begin{tabular}{|c|c|c|c|c|}
\hline \multicolumn{5}{|c|}{ Set No. 1} \\
\hline \multirow[t]{2}{*}{ Core No. } & Permeability & $\begin{array}{l}\text { Effective } \\
\text { porosity }\end{array}$ & Length & Diameter \\
\hline & {$[\mathrm{mD}]$} & [\%] & {$[\mathrm{cm}]$} & [cm] \\
\hline $\mathbf{A 8}$ & 105.47 & 26.17 & 5.62 & 2.54 \\
\hline A61 & 53.97 & 26.44 & 5.49 & 2.54 \\
\hline A63 & 36.20 & 26.59 & 5.60 & 2.54 \\
\hline A16 & 22.54 & 21.28 & 5.78 & 2.54 \\
\hline \multicolumn{5}{|c|}{ Parameters for set of 4 cores } \\
\hline \multicolumn{4}{|c|}{ Average permeability [mD] } & 54.5 \\
\hline \multicolumn{4}{|c|}{ Permeability for whole core set $(1 / \mathrm{k}=1 \mathrm{k} 1+1 \mathrm{k} 2+\ldots 1 / \mathrm{kn})[\mathrm{mD}]$} & 10.0 \\
\hline \multicolumn{4}{|c|}{ Average effective porosity [\%] } & 25.1 \\
\hline \multicolumn{4}{|c|}{ Length of core set $[\mathrm{cm}]$} & 22.49 \\
\hline \multicolumn{5}{|c|}{ Set No. 2} \\
\hline \multirow[t]{2}{*}{ Core No. } & Permeability & $\begin{array}{l}\text { Effective } \\
\text { porosity }\end{array}$ & Length & Diameter \\
\hline & {$[\mathrm{mD}]$} & [\%] & {$[\mathrm{cm}]$} & {$[\mathrm{cm}]$} \\
\hline A68 & 64.51 & 29.15 & 5.54 & 2.54 \\
\hline A1-4 & 31.22 & 18.03 & 5.62 & 2.54 \\
\hline A14 & 25.18 & 22.5 & 5.74 & 2.54 \\
\hline A15 & 25.18 & 19.18 & 5.70 & 2.54 \\
\hline \multicolumn{5}{|c|}{ Parameters for set of 4 cores } \\
\hline \multicolumn{4}{|c|}{ Average permeability [mD] } & 36.5 \\
\hline \multicolumn{4}{|c|}{ Permeability for whole core set $(1 / \mathrm{k}=1 \mathrm{k} 1+1 \mathrm{k} 2+\ldots 1 / \mathrm{kn})[\mathrm{mD}]$} & 7.9 \\
\hline \multicolumn{4}{|c|}{ Average effective porosity [\%] } & 22.2 \\
\hline \multicolumn{4}{|c|}{ Length of core set [cm] } & 22.60 \\
\hline \multicolumn{5}{|c|}{ Set No. 3} \\
\hline \multirow[t]{2}{*}{ Core No. } & Permeability & $\begin{array}{l}\text { Effective } \\
\text { porosity }\end{array}$ & Length & Diameter \\
\hline & {$[\mathrm{mD}]$} & [\%] & {$[\mathrm{cm}]$} & {$[\mathrm{cm}]$} \\
\hline $\mathbf{A 8 1}$ & 70.63 & 37.56 & 5.56 & 2.54 \\
\hline A65 & 53.28 & 26.19 & 5.49 & 2.54 \\
\hline A2-4 & 28.27 & 17.92 & 5.86 & 2.54 \\
\hline $\mathbf{A 1 8}$ & 27.95 & 21.62 & 5.71 & 2.54 \\
\hline \multicolumn{5}{|c|}{ Parameters for set of 4 cores } \\
\hline \multicolumn{4}{|c|}{ Average permeability [mD] } & 45.0 \\
\hline \multicolumn{4}{|c|}{ Permeability for whole core set $(1 / \mathrm{k}=1 \mathrm{k} 1+1 \mathrm{k} 2+\ldots 1 / \mathrm{kn})[\mathrm{mD}]$} & 9.6 \\
\hline \multicolumn{4}{|c|}{ Average effective porosity [\%] } & 25.8 \\
\hline \multicolumn{4}{|c|}{ Length of core set [cm] } & 22.62 \\
\hline
\end{tabular}




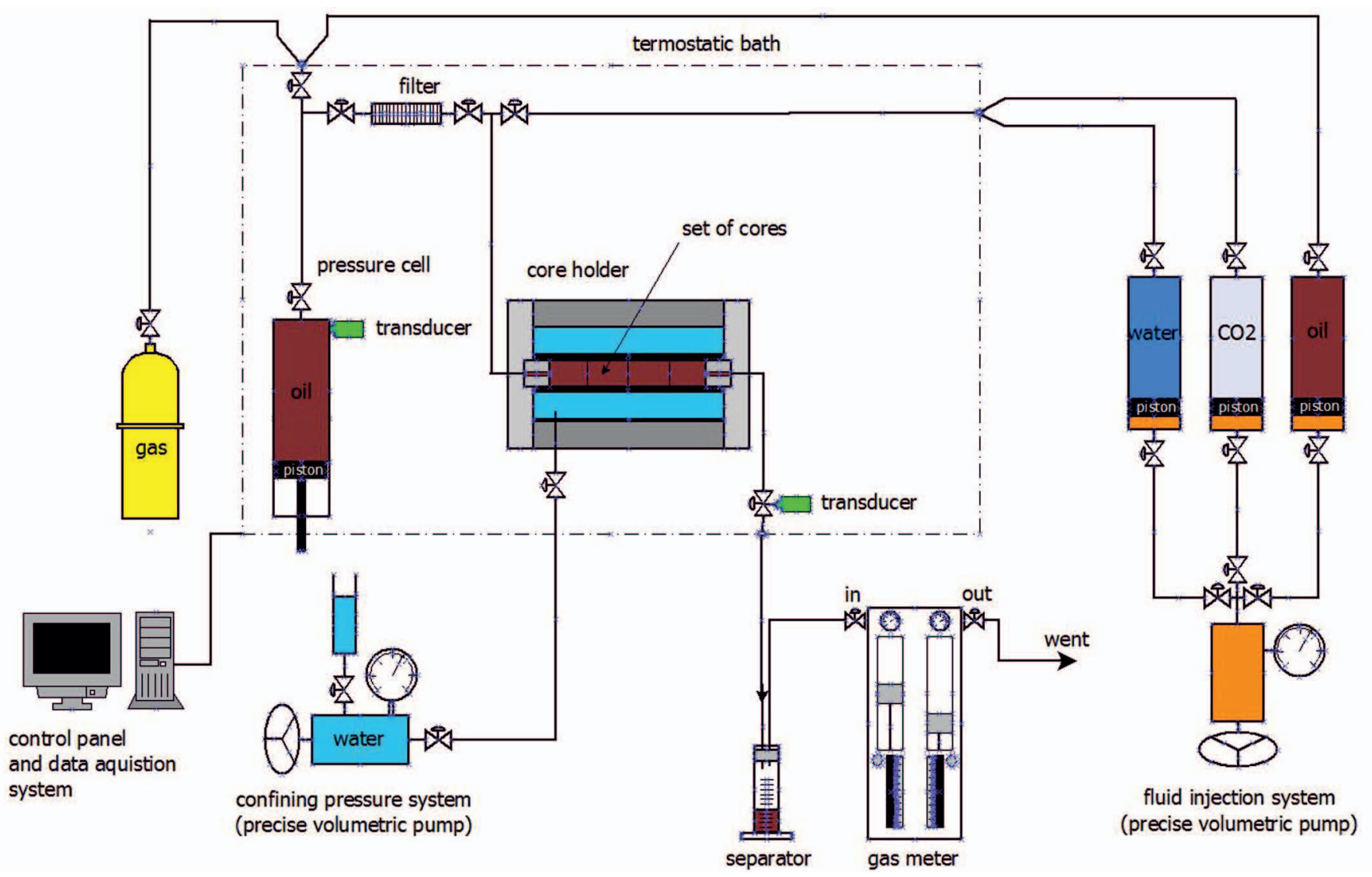

Fig. 1. Scheme of PVT apparatus adapted to perform coreflooding experiments on long cores

$2.54 \mathrm{~cm}$ and a length of $5.49 \div 5.86 \mathrm{~cm}$. Table 1 shows the parameters of the cores used with specified values of porosity and permeability. Cores in each set were stacked according to decreasing permeability.

\section{Experimental design and setup}

Its main element was a high-pressure water pump that maintained a high sealing pressure (approximately $150 \mathrm{bar}$ higher than the pressure of the media flowing through the cores). The experiments were carried out using the nonmercury PVT Chandler Engineering - Model 2370-3000-G apparatus, originally designed to study the phase properties of reservoir fluids, that was appropriately adapted for gas-oil displacement experiments with long drilling cores. Modification of the apparatus consisted of mounting (to the thermostatic bath) an additional core chamber (core holder) for maintaining the cores under the specific pressure and temperature conditions while conducting the coreflooding process. The scheme of the set used in the studies is shown in Figure 1. An appropriately selected and prepared set of drill cores is placed in a rubber sleeve and then in the core holder. The material of the sleeve is made of a special blend, which is resistant to high pressures and temperatures. In addition, for the duration of the test, the sleeve material is resistant to hydrocarbons, $\mathrm{CO}_{2}, \mathrm{H}_{2} \mathrm{~S}$ and other impurities contained in both displaced and injected fluids. The leak protection between the rubber sleeve and the lateral walls cores was realized by the pressurized water system (light blue in the scheme in Figure 1). The main element of the sealing system, was a high-pressure water pump that maintained a high confining pressure (approximately 150 bar higher than the pressure of the media flowing through the cores).

\section{Experimental procedure}

All series of experiments whose key parameters are shown in Table 2 were carried out according to the procedure described below:

1. Properly prepared cores were assembled into a core battery (in a rubber sleeve) and placed in a core holder. Then the specific confining pressure of the sleeve was applied, and the air bath was heated to the appropriate temperature $\left(119^{\circ} \mathrm{C}\right)$.

2. After reaching the appropriate temperature of the system, the recombination of live (reservoir) oil was made (using separator samples of oil and gas) up to the saturation pressure $\left(\mathrm{P}_{\mathrm{SAT}}\right)$ of 350 bar.

3. The water cores were saturated with water, thus determining the pore volume (PV).

4. The cores were saturated with previously prepared live oil, thus determining the pore hydrocarbon pore volume (HCPV). 
5. Coreflooding was started with water injection (waterflooding) with constant pressure and flow rate, which continued until water breakthrough. Then WAG process was applied (with the same pressure and flow rate), starting with carbon dioxide injection.

6. In each case, the total volume of water and gas in the WAG process was $1.6 \mathrm{PV}$.
Table 2. Summary of basic WAG process parameters for conducted experiments

\begin{tabular}{|c|c|c|c|c|}
\hline $\begin{array}{c}\text { Test } \\
\text { No. }\end{array}$ & $\begin{array}{c}\text { Core set } \\
\text { No. }\end{array}$ & $\begin{array}{c}\text { Water to } \\
\text { gas ratio }\end{array}$ & $\begin{array}{c}\text { Slug size } \\
{[\mathrm{PV}]}\end{array}$ & $\begin{array}{c}\text { Injection } \\
\text { pattern }\end{array}$ \\
\hline 1 & 3 & $1: 0$ & - & waterflooding \\
\hline 2 & 3 & $1: 1$ & 0.1 & WAG \\
\hline 3 & 2 & $1: 1$ & 0.2 & WAG \\
\hline 4 & 1 & $1: 1$ & 0.4 & WAG \\
\hline 5 & 2 & $1: 1$ & 0.2 & TWAG \\
\hline 6 & 1 & $2: 1$ & 0.2 & WAG \\
\hline 7 & 2 & $1: 2$ & 0.2 & TWAG \\
\hline
\end{tabular}

\section{Results}

The research has unambiguously demonstrated the high effectivity of the WAG process under the specified thermobaric conditions for the used media, as well as the rocks forming
Total recovery of oil (including waterflooding) was found in the range of $82 \div 97 \%$ (Figure 3 ). The highest value of the recovery factor was obtained in study No. 7 (96.9\%), while

Table 3. Summary of research results

\begin{tabular}{|c|c|c|c|c|c|c|c|c|c|}
\hline $\begin{array}{c}\text { Test } \\
\text { No. }\end{array}$ & $\begin{array}{c}\text { Total amount of } \\
\text { fluids injected } \\
{[\mathrm{PV}]}\end{array}$ & $\begin{array}{c}\text { Amount of } \\
\mathrm{CO}_{2} \text { injected } \\
{[\mathrm{PV}]}\end{array}$ & $\begin{array}{c}\mathrm{RF} \\
{[\%]}\end{array}$ & $\begin{array}{c}\mathrm{RF}_{\mathrm{WAG}} \\
{[\%]}\end{array}$ & $\begin{array}{c}\text { Amount of water } \\
\text { injected till } \\
\text { breakthrough } \\
{[\mathrm{PV}]}\end{array}$ & $\begin{array}{c}\text { RF till water } \\
\text { breakthrough } \\
{[\%]}\end{array}$ & $\begin{array}{c}\mathrm{TRF} \\
\text { max } \\
{[-]}\end{array}$ & $\begin{array}{c}\text { UF } \\
{[\mathrm{MSCF} / \mathrm{STB}]}\end{array}$ & $\begin{array}{c}\mathrm{Sw} \\
{[\%]}\end{array}$ \\
\hline 1 & 1.98 & 0.00 & 54.7 & - & 0.38 & 43.8 & - & - & 36.6 \\
\hline 2 & 1.95 & 0.80 & 96.3 & 93.0 & 0.35 & 47.1 & 1.44 & 4.71 & 36.5 \\
\hline 3 & 2.04 & 0.80 & 94.2 & 88.1 & 0.44 & 51.5 & 1.61 & 5.30 & 33.7 \\
\hline 4 & 1.91 & 0.80 & 96.6 & 93.6 & 0.31 & 46.5 & 2.12 & 5.43 & 44.9 \\
\hline 5 & 1.92 & 0.55 & 82.4 & 66.2 & 0.32 & 48.0 & 1.47 & 4.60 & 36.7 \\
\hline 6 & 1.88 & 0.60 & 92.9 & 86.7 & 0.28 & 46.9 & 3.01 & 4.26 & 44.5 \\
\hline 7 & 1.93 & 0.90 & 96.9 & 94.2 & 0.33 & 47.6 & 1.56 & 5.52 & 40.2 \\
\hline
\end{tabular}

the reservoir model, as the tertiary oil recovery method. During the experiments (depending on the variant), it was injected from 0 (waterflooding) to $0.9 \mathrm{PV}$ of carbon dioxide, while the total amount of fluids used during coreflooding (waterflooding + WAG) was $1.88 \div 2.04 \mathrm{PV}$. The saturation of the reservoir model with irreducible water $(\mathrm{Sw})$ was in the range of $36 \div 45 \%$. The volume of injected water until the breakthrough was $0.28 \div 0.44 \mathrm{PV}$, while the recovery factor at the time of water breakthrough (and thus at the start of the WAG process) was about $44 \div 52 \%$. A tabular summary of the results is shown in Table 3. An example of an experiment run with reference to the baseline test is shown in Figure 2.
1:1 WAG; $0.2 \mathrm{PV}$

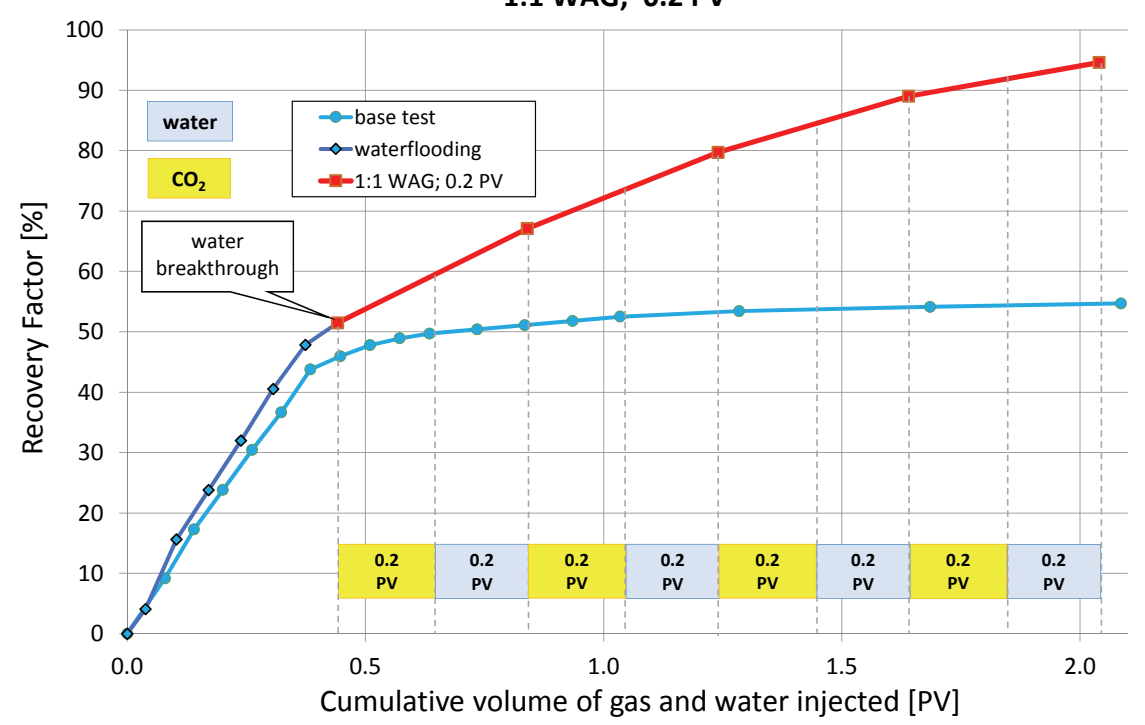

Fig. 2. Exemplary plot showing the coreflooding process in relation to recovery factor 
the lowest in study No. 5 (82.4\%), which positively correlates with the amount of injected gas. In relation to the baseline test, which allowed to obtain the recovery factor about $55 \%$, the use of the WAG process results in a significant increase in the recovery factor of $28 \div 42 \%$ (Figure 3 ).

Figure 4 shows a comparison of recovery factors (in respect of oil remaining in the reservoir model after waterflooding $-\mathrm{RF}_{\mathrm{WAG}}$ ) and their curves course between different variants of WAG process. Final oil recovery (at the end of coreflooding) is at a very similar level (RF in the range of $92.9 \div 96.9 \%, \mathrm{RF}_{\mathrm{WAG}}$ in the range of $86.7 \div 94.2 \%$ ) except the fifth test (1:1 TWAG; $0.2 \mathrm{PV})$, where a significantly lower recovery factor $\left(\mathrm{RF}-82.4 \%, \mathrm{RF}_{\mathrm{WAG}}-66.2 \%\right)$ was obtained.

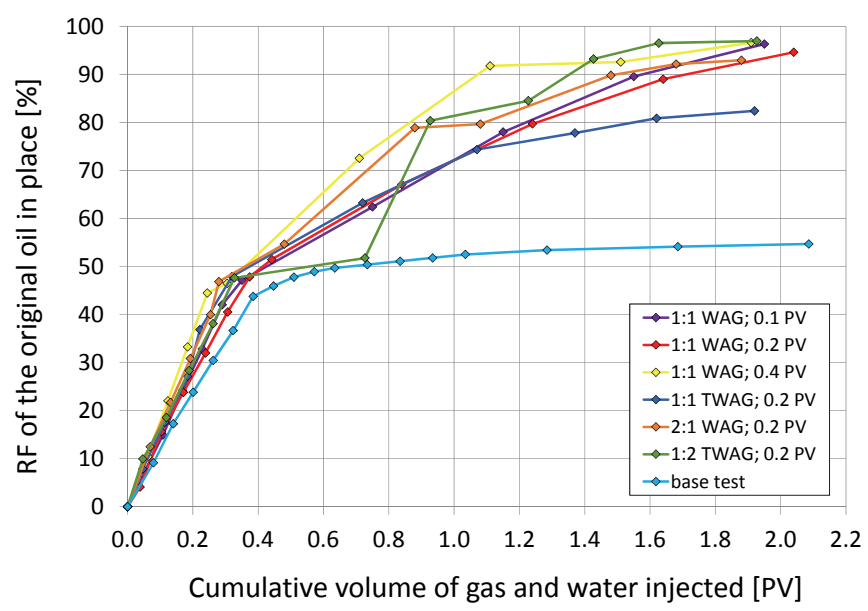

Fig. 3. Summary of coreflooding results showed as ultimate RF curves (waterflooding + WAG process)

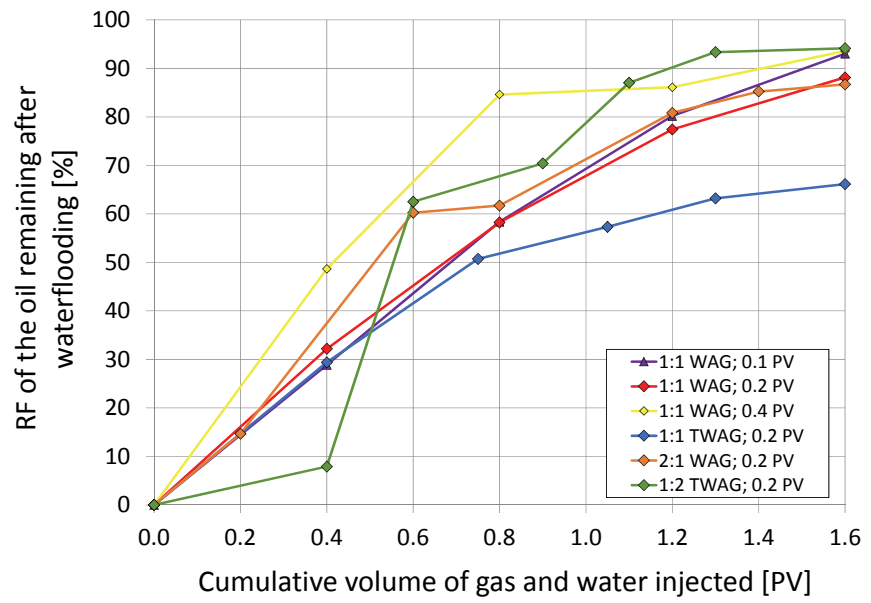

Fig. 4. Comparison of recovery factor curves of oil remainig after waterflooding $\left(\mathrm{RF}_{\mathrm{WAG}}\right)$

In the group of 3 studies that differ in slug size, with the same water to gas ratio and injection pattern (tests 2, 3 and 4), no significant difference in total recovery factor is observed. The differences are evident in the displacement process, where the $0.4 \mathrm{PV}$ variant from the beginning is significantly more efficient, and at halfway through the WAG process (after injection of $0.8 \mathrm{PV}$ fluids) reaches $85 \%$ of RF (Figure 4). The other two variants show almost identical recovery factor curves, and in the middle of the WAG process, they obtain about 58\% RF. The variant from the sixth test $2: 1 \mathrm{WAG}$; $0.2 \mathrm{PV}$ ) was exceptionally good, and despite a significantly smaller (by 25\%) amount of injected gas compared to the variant from the third test (1: $1 \mathrm{WAG}$; $0.2 \mathrm{PV})$ it achieved very similar recovery factor (Figure 3-4). On the other hand, the fifth test (1:1 TWAG; 0.2 PV), with a slightly less amount of gas injected (about $8 \%$ ) when compared to the sixth test, showed significantly worse efficiency (Figure 3-4). Based on the above considerations it should be noted that in addition to the amount of gas being injected, a very important factor influencing the efficiency of the WAG processes is the injection pattern. In this particular case, it was more efficient to apply an increased water to gas ratio (i.e. injecting larger portions of water) than to gradually reduce the amount of gas in subsequent steps.

In practice, to facilitate the evaluation of all the corefloods conducted with various amounts of injected gas, two factors are often used:

1. Tertiary Recovery Factor - TRF. It allows to normalize the recoveries in respect to the amount of injected gas. TRF is a dimensionless quantity defined by the equation:

$$
T R F=\frac{\frac{V_{o}}{V_{\mathrm{ROIP}}}}{V_{\mathrm{CO}_{2}}}[-]
$$

where:

$V_{o} \quad$ - the volume of recovered oil,

$V_{\text {ROIP }}$ - the volume of residual oil in place,

$V_{\mathrm{CO}_{2}}$ - cumulative volume of injected $\mathrm{CO}_{2}$.

2. Gas Utilization Factor - UF. It is commonly used to evaluate EOR field projects and is defined as the volume of gas injected under standard conditions $\left(\mathrm{T}=60^{\circ} \mathrm{F}\right.$, $\mathrm{P}=14.7 \mathrm{psi}$ ), to produce a barrel of oil.

$$
U F=\frac{V_{g}[M S C F]}{Q_{o}[B b l]}
$$

where:

$V_{\mathrm{CO}_{2}}$ - volume od injected gas in standard conditions, $Q_{o} \quad$ - volume of recovered oil in standard conditions.

In most cases, gas injection lead to increased production cost (although this is not a rule), especially when gas has to be purchased and transported to the injection site. These factors are particularly useful in the case of economic analysis of such projects, as they allow to choose the most economically advantageous option of the method. 
The most efficient utilization of injected gas, according to the TRF factor (the higher the value, the more advantageous variant is) is observed for variant 2:1 WAG; $0.2 \mathrm{PV}$ and it shows a maximum value of 3.01 . The worst is 1:2 TWAG; $0.2 \mathrm{PV}$, while for other variants the TRF values are similar (Figure 5, Table 3).

On the basis of the UF (Figure 6) analysis, it can be concluded that, similarly to the TRF, it indicates the variant from the study 7 (1:2 TWAG; 0.2 PV) as the least effective, while the variant from the study $6(2: 1 ; 0.2 \mathrm{PV})$ as the most effective. The lower the value of the UF factor, the better the performance of the variant, because as described above, UF indicates the amount of gas that is needed to recover a specified amount of oil.

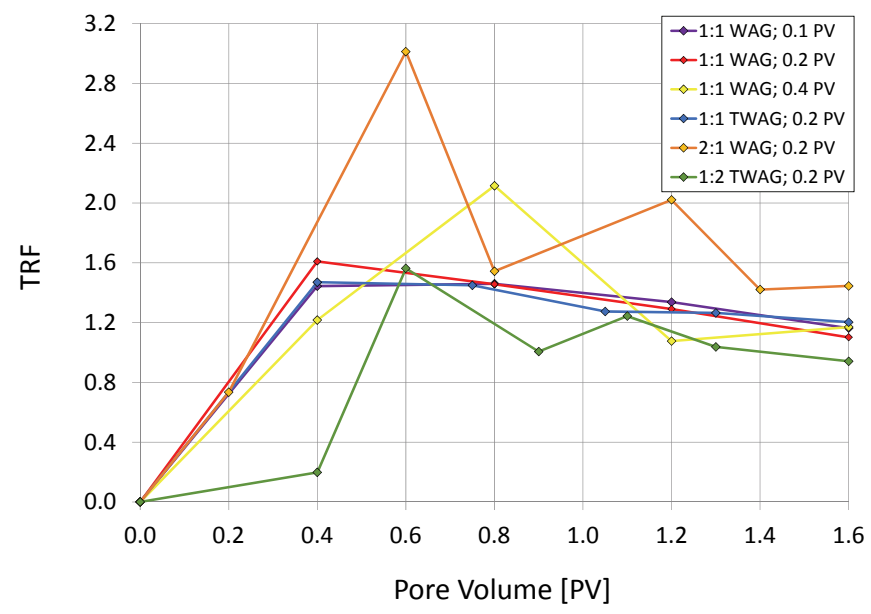

Fig. 5. Comparison of tertiary recovery factor (TRF) curves of different WAG process variants

UF

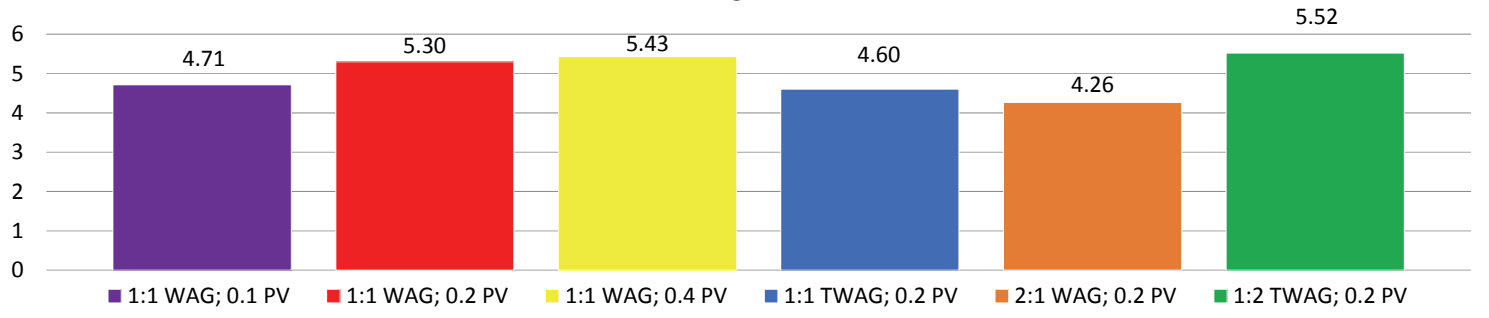

Fig. 6. Comparison of gas utilization factors (UF) between different variants of WAG process

\section{Conclusions}

1. The results of experimental studies have confirmed the suitability of conducting analyses using a long core reservoir model coupled with PVT apparatus for evaluating different variants of the WAG process under given PT conditions and the presence of original fluids and reservoir rocks.

2. As a result of the coreflooding experiments, high recovery factors for the WAG process were obtained, ranging from $82.4 \div 96.9 \%$. The application of the WAG process as a tertiary recovery method (at the time of water breakthrough) yields significant results through an increase in the level of oil recovery (by 28 to $42 \%$ ) when compared to the continuation of traditional waterflooding.

3. The course of the WAG process is different for each variant (despite the similarities in the ultimate recovery factor). Large disproportions are most visible in the middle of the process (after injecting of 0.8 PV fluids), as is shown in Figure 4.

4. On the basis of the results obtained, it must be noted that the effectiveness of the WAG process depends not only on the amount of injected gas, but also largely on the injection pattern used.

5. The research has unambiguously demonstrated that the WAG process, conducted under conditions characteristic for domestic oil resources in carbonate reservoirs, gives promising results. Positive results prompting further re- search in this area, including the utilization of other gases (e.g. post-process gas with $\mathrm{H}_{2} \mathrm{~S}$, flue gas), influence of water/ salinity composition on WAG efficiency, or determination of the appropriate moment of implementation of the tertiary recovery method. It is also worthwhile to focus on different variants of methods such as FWAG, polymer-alternating gas (PAG) or surfactant-alternating gas (SAG).

6. Due to documented climatic changes (which are occurring as the result of increased greenhouse gases concentration in the atmosphere) the use in EOR gases such as flue gas, post-process gas, $\mathrm{CO}_{2}$ or $\mathrm{H}_{2} \mathrm{~S}$ brings additional environmental, economic and social benefits. Hydrocarbon reservoirs are a great place to store these gases, as they have proven sealability and proper geological structure recognition. Combining the benefits of increased oil recovery with the elimination of pollutant gases from the atmosphere is yet another important argument for WAG process implementation.

7. Nowadays, the research on the development and implementation of modern EOR methods is a priority for the largest oil \& gas research centers in the world. In order to keep pace with world standards, we should intensify our research efforts and bring EOR methods into the national reserves as quickly as possible. 
Please cite as: Nafta-Gaz 2017, no. 11, pp. 864-870, DOI: 10.18668/NG.2017.11.06

Article contributed to the Editor 2.08.2017. Approved for publication 10.09.2017.

The article is based on research entitled: Evaluation of acid gas WAG injection process in oil-displacement efficiency - work the Oil and Gas Institute - National Research Institute, order no.: 1887/KB/17/01 of 13.01.2017, archive no.: DK-510-29/17.

\section{Literature}

[1] Awan R., Teigland R., Kleppe J.: EOR Survey in the North Sea. SPE paper No. 99546, SPE/DOE Symposium on Improved Oil Recovery, Tulsa, Oklahoma, USA, April 2006, pp. 16.

[2] Caudle B.H., Dyes A.B.: Improving Miscible Displacement by Gas-Water Injection. Petroleum Transactions 1958, vol. 213, pp. 281-284.

[3] Christensen J.R., Stenby E.H., Skauge A.: Review of WAG Field Experience. SPE Reservoir Evaluation \& Engineering 2001, vol. 4, no. 2, pp. 97-106.

[4] Christensen J.R., Stenby E.H., Skauge A.: Review of WAG Field Experience. SPE paper No. 39883, SPE International Petroleum Conference and Exhibition of Mexico, Villahermosa, Mexico, March 1998, pp. 357-370.

[5] Kulkarni M.M., Rao D.N.: Experimental investigation of miscible and immiscible Water-Alternating-Gas (WAG) process performance. Journal of Petroleum Science and Engineering 2005, vol. 48, no. 1-2, pp. 1-20.

[6] Lubaś J.: O potrzebie bardziej dynamicznego wdrażania metod wspomagania wydobycia ropy naftowej z krajowych złóż. Nafta-Gaz 2013, no. 10, pp. 744-750.

[7] Lubaś J., Szott W., Dziadkiewicz M.: Analiza możliwości zwiększenia stopnia sczerpania zasobów złóż ropy naftowej w Polsce. Nafta-Gaz 2012, no. 8, pp. 481-489.

[8] Miłek K., Szott W.: Zastosowanie symulacji złożowych do analizy porównawczej procesu EOR na przyktadzie wybranych metod wspomagania. Nafta-Gaz 2015, no. 3, pp. 167-176.
[9] Such J., Szott W.: Symulacyjne badania procesu przemiennego zatłaczania wody i gazu (WAG) stosowanego dla zwiększania efektywności wypierania ropy $w$ złożu. Prace Instytutu Górnictwa Naftowego i Gazownictwa 1997, vol. 89, pp. 21.

[10] Verma M.K.: Fundamentals of Carbon Dioxide-Enhanced Oil Recovery $\left(\mathrm{CO}_{2}-\right.$ EOR $)$ - A Supporting Document of the Assessment Methodology for Hydrocarbon Recovery Using $\mathrm{CO}_{2}-$ EOR Associated with Carbon Sequestration. U.S. Geological Survey Open-File Report 2015, pp. 19.

[11] Wang Y., Orr F.M.: Calculation of Minimum Miscibility Pressure. SPE paper No. 39683, SPE/DOE Improved Oil Recovery Symposium, Tulsa, Oklahoma, USA, April 1998, pp. 19-22.

[12] Wojnicki M.: Wspomaganie wydobycia ropy metoda naprzemiennego zattaczania wody i gazu (WAG). Wiadomości Naftowe i Gazownicze 2017, no. 8, pp. 4-8.

\section{OFERTA}

\section{ZAKŁAD BADANIA ZŁÓŻ ROPY I GAZU}

Zakres działania:

- $\quad$ pobór wgłębnych i powierzchniowych próbek płynów złożowych;

- kompleksowe badania i analizy zmian fazowych próbek płynów złożowych na zestawie aparatów PVT firmy Chandler i Ruska;

- modelowanie procesu wypierania ropy gazem na fizycznym modelu złoża (tzw. "cienka rurka");

- pomiar lepkości ropy wiskozymetrem kulkowym lub kapilarnym w warunkach PT;

- optymalizacja procesów powierzchniowej separacji ropy naftowej;

- laboratoryjne i symulacyjne badania warunków wytrącania się parafin, asfaltenów w ropie oraz tworzenia się hydratów w gazie;

- badanie skuteczności działania chemicznych środków zapobiegających tworzeniu się hydratów;

- laboratoryjne modelowanie procesów wypierania ropy gazem w warunkach zmieszania faz;

- badanie procesów sekwestracji $\mathrm{CO}_{2}$ w solankowych poziomach wodonośnych, nasyconych gazem ziemnym;

- badania na długich rdzeniach wiertniczych dla oceny efektywności metod zwiększenia stopnia odzysku ropy.

Kierownik: dr inż. Marcin Warnecki

Adres: ul. Armii Krajowej 3, 38-400 Krosno

Telefon: 134368941 w. 5226

Faks: 134367971

E- mail: marcin.warnecki@inig.p

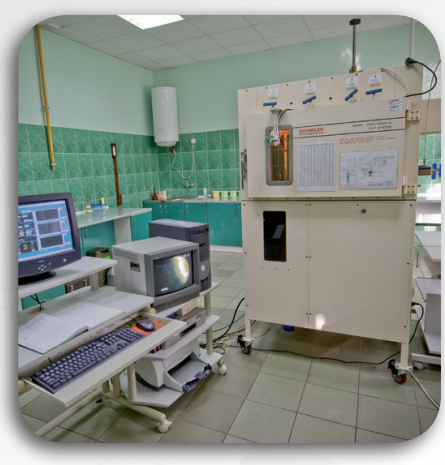

M.Sc., Eng., Department of Oil and Gas Reservoir

Testing

Onstitute - National Research Institute

1-503 Kraków

E-mail: miroslaw.wojnicki@inig.pl 